\title{
The Real Jesus
}

Victor Christianto, www.sci4God.com

Sumber: National Geographic Magazine

Edisi: December 16th 2017

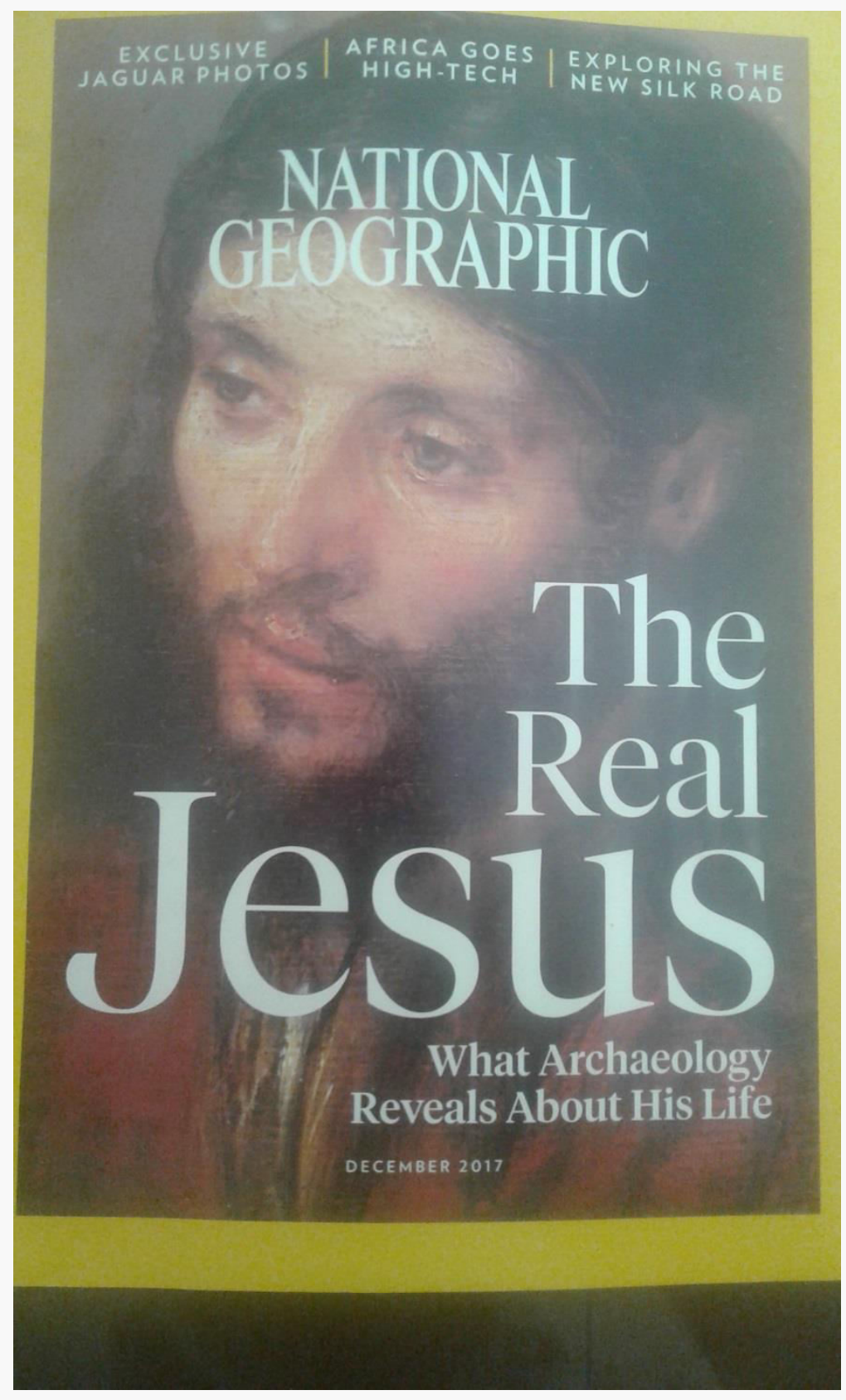




\section{Resensi}

Edisi desember dari majalah internasional National Geographic mengangkat suatu topic yang telah menantang ribuan bahkan jutaan pemikir, teolog, dan ahli sejarah, yakni kontroversi seputar siapakah Yesus dari Nazaret.

Sebagai sebuah majalah semi-ilmiah dengan tiras yang cukup besar, tentu kita mesti mengangkat jempol atas keberanian majalah tersebut untuk mengangkat topik yang bagi sebagian orang disebut "politically incorrect." Tentunya National Geographic meliput dengan sudut pandang senetral mungkin, yakni sudut pandang seorang arkeolog. Laporan tentang berbagai situs sejarah diliput dengan sangat menarik oleh Kristin Romney, didukung oleh fotografi kelas dunia oleh Simon Norfolk.

Di antara fotografi yang diliput adalah situs makam suci Yesus yang barubaru ini dibongkar oleh sebuah tim arkeologi, situs ini disebut Edicule. Jika Anda membaca klip Youtube tentang proses penggalian situs tersebut, maka Anda pasti heran bahwa ada semacam suara terompet di langit Yerusalem ketika makam suci tersebut dibongkar.

Selain itu ada foto tentang kolam di Betsaida, di mana Yesus pernah menyembuhkan seorang buta menurut penuturan Injil Yohanes. Banyak ahli biblika yang meragukan historisitas Injil Yohanes, namun ternyata penggalian arkeologi menunjukkan adanya sisa-sisa kolam tersebut.

Tentu edisi The Real Jesus ini sangat direkomendasikan untuk dibaca tidak saja sebagai bacaan menjelang Natal, namun juga bagi para teolog yang telah jenuh dengan pelbagai studi yang bernuansa skeptik tentang pribadi Yesus, sebagaimana misalnya diusung oleh kelompok liberal The Jesus Seminar. Thank you so much to Susan Goldberg, Editor in Chief of National Geographic magazine.

Soli Deo Gloria!

Desember $16^{\text {th }}, 2017^{--}$VC 